\title{
The role of VASP in CGMP-mediated vascular smooth muscle relaxation
}

\author{
Staffan Hildebrand ${ }^{1,2^{*}}$, Katrin Zimmermann ${ }^{1,2}$, Daniela Wenzel ${ }^{3}$, Bernd K Fleischmann ${ }^{3}$, Alexander Pfeifer ${ }^{1,2}$ \\ From 6th International Conference on cGMP: Generators, Effectors and Therapeutic Implications \\ Erfurt, Germany. 28-30 June 2013
}

\section{Background}

Cyclic GMP (cGMP) is a major mediator of relaxation in the vascular system. cGMP is produced by the enzyme soluble Guanylyl Cyclase (sGC) in response to nitric oxide $(\mathrm{NO})$ released from neighbouring endothelial cells. cGMP activates Protein Kinase G (PKG), which in turn mediates vascular relaxation through phosophorylation of various targets. One of the major substrates of PKG is the VAsodilator-Stimulated Phosphoprotein (VASP). The role of VASP in vascular smooth muscle relaxation is currently unknown. However, recent studies show that VASP-deficient brown adipocytes have an increased

sGCß1

PKGI
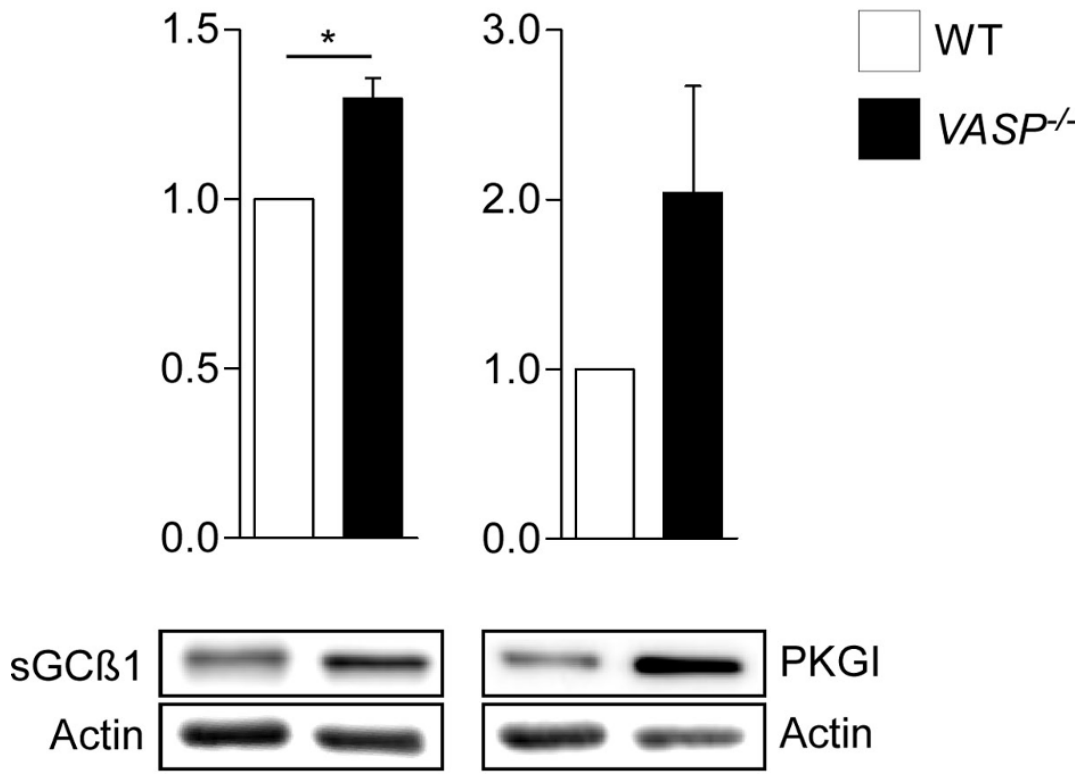

Figure 1 Expression of PKGI and the B1-subunit of sGC in VASP-/- and wild-type murine aortas as determined by western blotting N=3.

\footnotetext{
* Correspondence: shil@uni-bonn.de

${ }^{1}$ Institute of Pharmacology and Toxicology, University of Bonn, Bonn, NRW,

53105, Germany

Full list of author information is available at the end of the article
}

(c) 2013 Hildebrand et al; licensee BioMed Central Ltd. This is an Open Access article distributed under the terms of the Creative 
activity of the small GTPase Rac1 and elevated levels of sGC [1]. These data suggest a regulatory role for VASP in cGMP-mediated processes.

\section{Results}

Preliminary data acquired from the analysis of VASP-deficient (VASP-/-) mice provide evidence for the importance of VASP in the cGMP mediated relaxation pathway: VASP-/ - aortas show higher levels of PKG and sGC compared to wild type (see Figure 1), and increased sensitivity to NO-induced relaxation. Additionally, cultured vascular smooth muscle cells (VSMCs) transduced with a constitutively active Rac1 mutant (RacL61) show elevated sGC and PKG expression as well as increased PKG activity. Cultured VSMCs from VASP-/- aortas also demonstrate decreased proliferation rates compared to wild-type cells in preliminary experiments.

\section{Authors' details}

'Institute of Pharmacology and Toxicology, University of Bonn, Bonn, NRW, 53105, Germany. ${ }^{2}$ NRW International Graduate School BIOTECH-PHARMA, Bonn, NRW, 53105, Germany. ${ }^{3}$ Institute of Physiology I, University of Bonn, Bonn, NRW, 53105, Germany.

Published: 29 August 2013

\section{Reference}

1. Jennissen $K$, Siegel F, Liebig-Gonglach M, Hermann M-R, Kipschull S, van Dooren S, Kunz WS, Fässler R, Pfeifer A: A VASP-Rac-soluble guanylyl cyclase pathway controls cGMP production in adipocytes. Sci Signal 2012, 5:ra62.

doi:10.1186/2050-6511-14-S1-P28

Cite this article as: Hildebrand et al.: The role of VASP in cGMP-

mediated vascular smooth muscle relaxation. BMC Pharmacology and

Toxicology 2013 14(Suppl 1):P28.

\section{Submit your next manuscript to BioMed Central} and take full advantage of:

- Convenient online submission

- Thorough peer review

- No space constraints or color figure charges

- Immediate publication on acceptance

- Inclusion in PubMed, CAS, Scopus and Google Scholar

- Research which is freely available for redistribution

Submit your manuscript at www.biomedcentral.com/submit
C Biomed Central 